\title{
Tumour necrosis factor- $\alpha$ causes an increase in blood-brain barrier permeability during sepsis
}

\author{
N. TSAO, H. P. HSU, C. M. WU*, C. C. LIU† and H. Y. LEI \\ Departments of Microbiology and Immunology, *Anatomy and †Paediatrics, College of Medicine, National \\ Cheng Kung University, Tainan, Taiwan
}

\begin{abstract}
Blood-brain barrier (BBB) permeability during sepsis with Escherichia coli or Streptococcus pneumoniae was examined in a mouse model and measured by a circulating $\beta$-galactosidase tracer. The leakage of brain microvascular vessels during sepsis was confirmed by transmission electron microscopic examination of brain tissues stained with horseradish peroxidase. The increase of BBB permeability induced by $E$. coli and $S$. pneumoniae, which was maximal at $3 \mathrm{~h}$ and $12 \mathrm{~h}$ after injection, respectively, was transient because of rapid clearance of the bacteria from the blood. Tumour necrosis factor- $\alpha$ (TNF- $\alpha$ ) was stained on microvascular vessels of the brain during sepsis and intravenous injection of recombinant TNF- $\alpha$ also increased the BBB permeability. The increase in BBB permeability induced by either $E$. coli or $S$. pneumoniae could be inhibited by anti-TNF- $\alpha$ antibody. It was concluded that circulating TNF- $\alpha$ generated during sepsis induced the increase in BBB permeability.
\end{abstract}

\section{Introduction}

The incidence of septic shock, one of the commonest causes of mortality in clinical bacterial infection, is increasing steadily - especially in intensive care units - despite the availability of effective antibiotic treatment [1-3]. Cytokines such as tumour necrosis factor- $\alpha$ (TNF- $\alpha)$ and interleukin-1 (IL-1) are released in large amounts by monocytes, macrophages and other leucocytes in response to gram-negative or grampositive bacterial substances and play a critical role in the pathogenesis of septic shock [4-8]. Both gramnegative and gram-positive bacteria-induced sepsis also cause apoptosis of the thymocytes, and TNF- $\alpha$ involvement is common to both [9]. In addition to cytokine involvement in septic shock, there is evidence that overactivation of macrophages alters endothelial permeability in multiple organs during septic shock [10]. However, change of the blood-brain barrier (BBB) during sepsis was not clearly demonstrated.

The central nervous system (CNS) of mammals is considered to be an immunologically privileged site because of the lack of lymphatic drainage and its

Received 24 Jan. 2001; revised version accepted 14 March 2001.

Corresponding author: Dr H.Y. Lei (e-mail: hylei@mail.ncku. edu.tw). separation from the blood by the $\operatorname{BBB}[11,12]$. The BBB plays an important role in controlling the access of inflammatory cells and macromolecules into the brain by virtue of its selective permeability on its microvascular endothelial cells such as the presence of tight junctions, no formation of pinocytotic vesicles and wrapping by astrocytes [11-13]. Bacterial meningitis is associated with damage to the BBB [14]. Clinical evidence also suggests that bacterial meningitis results from bacteraemia or sepsis $[15,16]$. It was found previously that TNF- $\alpha$-induced cyclooxygenase 2 was responsible for increased BBB permeability in Escherichia coli-induced meningitis [17]. This study used a tracer to quantify the increase of BBB permeability $[17,18]$, and investigated the effect of gramnegative and gram-positive bacteria-induced sepsis on BBB permeability.

\section{Materials and methods}

Mice

C57BL/6 (B6) mice were purchased from either Jackson Laboratory, Bar Harbor, ME, USA or Charles River Japan (Atsugi, Japan). They were maintained on standard laboratory chow and water ad libitum in our animal centre and raised and cared for following the guidelines of the National Science Council of the Republic of China. Female 8-12-week-old mice were used in all experiments. 


\section{Induction of sepsis}

E. coli ATCC10536 and a Streptococcus pneumoniae strain of serotype 14, a clinical isolate from the National Cheng Kung University Hospital, were cultured in Luria-Bertani (LB) Broth and Todd Hewitt Broth (Difco), respectively, for $12 \mathrm{~h}$ at $37^{\circ} \mathrm{C}$ and were subcultured into fresh medium for another $3 \mathrm{~h}$. The concentration of bacteria was determined with a spectrophotometer with an $\mathrm{OD}_{600}$ of 1 equal to $10^{8} \mathrm{cfu} / \mathrm{ml}$ for $E$. coli and $10^{9} \mathrm{cfu} / \mathrm{ml}$ for $S$. pneumoniae. The $100 \%$ lethal dose (LD100) of E. coli and $S$. pneumoniae by peripheral intravenous (i.v.) injection in B6 mice was $2 \times 10^{8}$ and $1 \times 10^{9}$ cells, respectively. For the induction of sepsis, groups of four mice were inoculated intraperitoneally (i.p.) with $100 \mu \mathrm{l}$ of a suspension containing $1 \times 10^{7}$ cells (per mouse) in saline. In the antibody inhibition experiment, $40 \mu \mathrm{g}$ of rabbit anti-TNF- $\alpha$ antiserum (Genzyme Diagnostics, Cambridge, MA, USA) were administered i.v. simultaneously.

\section{Detection of increased vasopermeability of $B B B$} by $M 4$ tracer with $\beta$-galactosidase activity

An $E$. coli mutant (M4) that expressed $\beta$-galactosidase constitutively was used as a tracer to detect alterations in the vasopermeability of $\mathrm{BBB}[17,18]$. M4 was selected from $E$. coli $\mathrm{K}-12$ cultured in M63 medium

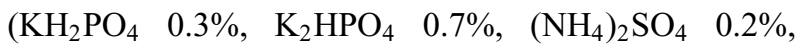
$\left.0.1 \mathrm{mM} \mathrm{FeSO}_{4}\right)$ containing lactose $0.2 \%$, vitamin $\mathrm{B}_{1} \quad 0.002 \%, \quad 1 \mathrm{mM} \mathrm{MgSO}_{4}$, isoleucine-leucine-valine $0.001 \%$ and 5-bromo-4-chloro-3-indolyl- $\beta$-D-galactopyranoside (X-Gal) $0.002 \%$. The M4 mutant expressed $\beta$-galactosidase constitutively and had a characteristic blue colony on medium containing $\mathrm{X}-\mathrm{Gal}$ without inducer. Strain M4 was avirulent (LD50>2 $\times 10^{9}$ cells) for mice and was removed from the circulation within $2 \mathrm{~h}$ of i.v. injection. No alteration of BBB permeability was found within $30 \mathrm{~min}$ after i.v. injection of $2 \times 10^{8} \mathrm{M} 4$ cells. To determine the timing of giving strain M4, more M4 tracers were detected in the brain at $2 \mathrm{~min}$ after i.v. injection than at $10 \mathrm{~min}$ or
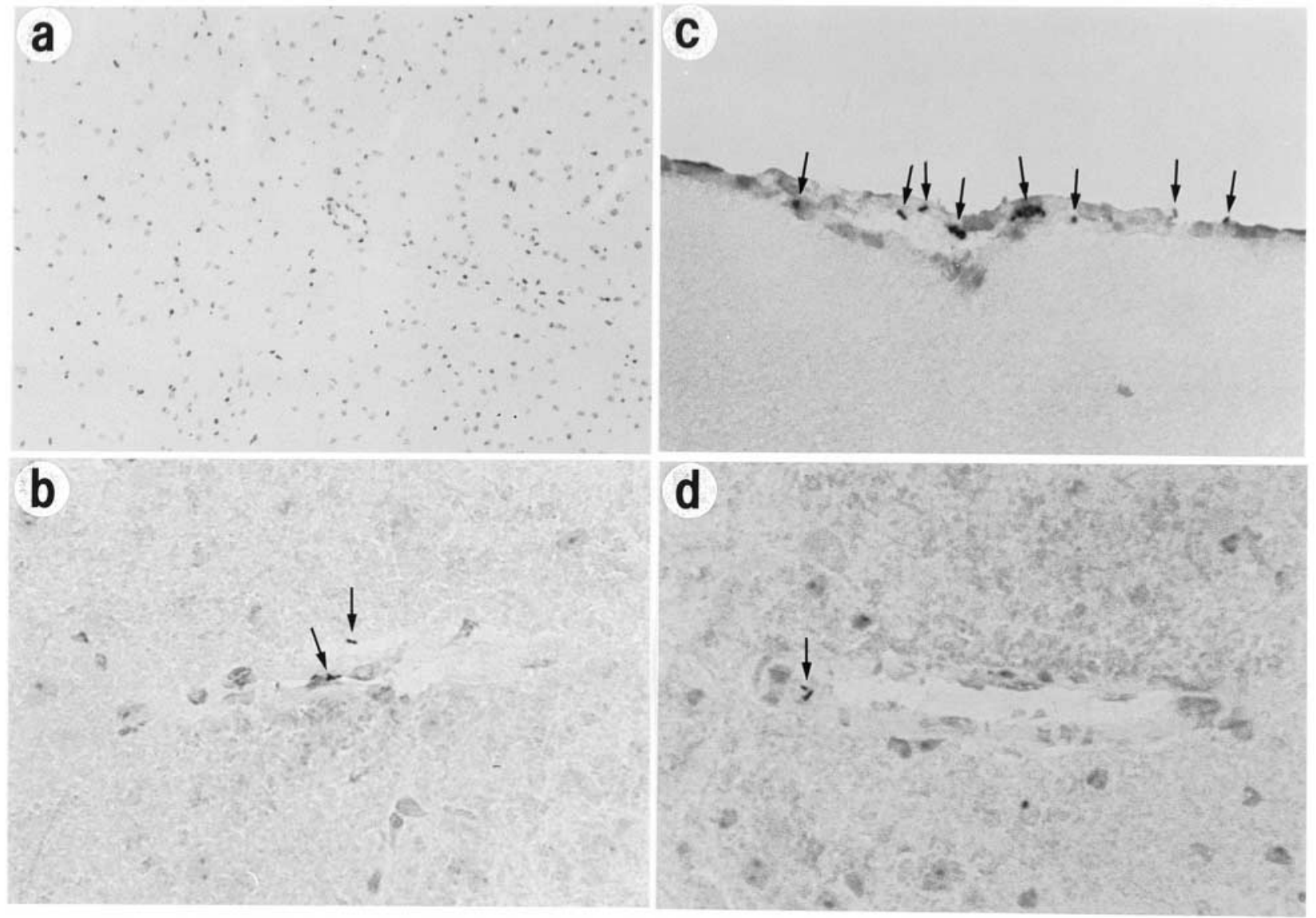

Fig. 1. Detection of the peripheral M4 tracer in brain by X-Gal staining in E. coli-induced sepsis. Groups of four B6 mice were inoculated i.p. with E. coli $1 \times 10^{7}$ cells/mouse and killed at various time points after injection. PBS was used as a control. The M4 tracers $\left(2 \times 10^{8}\right.$ cells $)$ were injected i.v. 2 min before each animal was killed; $4-\mu \mathrm{m}$ sections of frozen brain tissues were stained with X-Gal as described in Materials and methods. (a) PBS, $3 \mathrm{~h} ;$ (b) $1 \mathrm{~h}$; (c) $3 \mathrm{~h}$; (d) $6 \mathrm{~h}(\times 350)$. Arrow indicates the X-Gal-positive M4. 
30 min (data not shown). Therefore, strain M4 was an inert tracer at $2 \mathrm{~min}$ after injection. UV-inactivated strain M4 behaved in the same way as viable strain M4, but the latter could be amplified to quantify the degree of increased BBB permeability. To each mouse into which E. coli or $S$. pneumoniae was injected, $2 \times 10^{8}$ cells of the M4 tracer in $0.1 \mathrm{ml}$ of phosphate-buffered saline (PBS) were given i.v. 2 min before the mice were killed. The brains were removed, cryosectioned and fixed in glutaraldehyde (Merck GmbH, Darmstadt, Germany) $0.2 \%$. The M4 tracers in the tissues were detected by X-Gal staining (X-Gal $1 \mathrm{mg} / \mathrm{ml}$ in $20 \mathrm{~mm}$ potassium ferricyanide, $20 \mathrm{mM}$ potassium ferrocyanide and $2 \mathrm{mM}$ magnesium chloride at $37^{\circ} \mathrm{C}$ for $2 \mathrm{~h}$ ). To quantify the degree of BBB opening, the brains were removed aseptically after perfusion via cardiac puncture with PBS and were homogenised with gelatin 3\% in PBS. The samples were serially diluted and cultured at $37^{\circ} \mathrm{C}$ overnight. The number of X-Gal-positive cfu was quantified and expressed as the mean and SD/ mouse. Experiments were performed three times with similar results and one is presented.

\section{Immunohistochemistry}

Groups of four mice were killed by perfusion via cardiac puncture with PBS. The brains were removed, embedded in OCT compound (Miles, Elkhart, IN, USA) and frozen in liquid nitrogen. Sections were cut (4 $\mu \mathrm{m}$ ), fixed with ice-cold acetone for $3 \mathrm{~min}$ and then stained with rat anti-mTNF- $\alpha$ monoclonal antibody (MAb) (MP6-XT3; PharMingen, San Diego, CA, USA). The second antibody used was peroxidaseconjugated sheep anti-rat immunoglobulin G (IgG) (KirKegaard \& Perry Laboratory, Gaithersburg, MD, USA). A peroxidase stain of a reddish-brown colour was developed with an aminoethyl carbazole substrate kit (Zymed Laboratories, San Francisco, CA, USA) [17-19].

\section{Transmission electron microscopy}

Mice under anaesthesia were perfused through the heart with saline followed by $100-130 \mathrm{ml}$ of fixative containing paraformaldehyde $4 \%$ and glutaraldehyde $0.5 \%$ in PBS. The brains were removed and $40-\mu \mathrm{m}$ sections of the cortex were cut. After several washes, sections were treated with osmium tetroxide $1-1.5 \%$ in $0.1 \mathrm{M}$ sodium cacodylate solution at $4^{\circ} \mathrm{C}$ for $1-2 \mathrm{~h}$, dehydrated in a graded series of ethanol, cleared in propylene oxide and flat-embedded in plastic. The sections were examined with an electron microscope (JEOL JEM-1200EX) at $75 \mathrm{kV}$ [20]. To determine the microscopic change of $\mathrm{BBB}$, each mouse was given horseradish peroxidase (type IV, Sigma) $5 \mathrm{mg}$ i.v. $10 \mathrm{~min}$ before it was killed. The sections were incubated with diaminobenzidine solution for $15-30 \mathrm{~min}$ according to the standard protocol [21] to localise the exogenous peroxidase activity.

\section{Detection of remnant bacteria in the blood}

Groups of four mice were inoculated i.p. with (per mouse) $1 \times 10^{7}$ cells of $E$. coli or $S$. pneumoniae. At various times after injection, blood was collected into heparin. The samples were serially diluted and were poured into LB agar (for E. coli) or blood agar (for $S$. pneumoniae) and incubated at $37^{\circ} \mathrm{C}$ overnight. The number of cfu was quantified and expressed as the mean and $\mathrm{SD} /$ mouse.

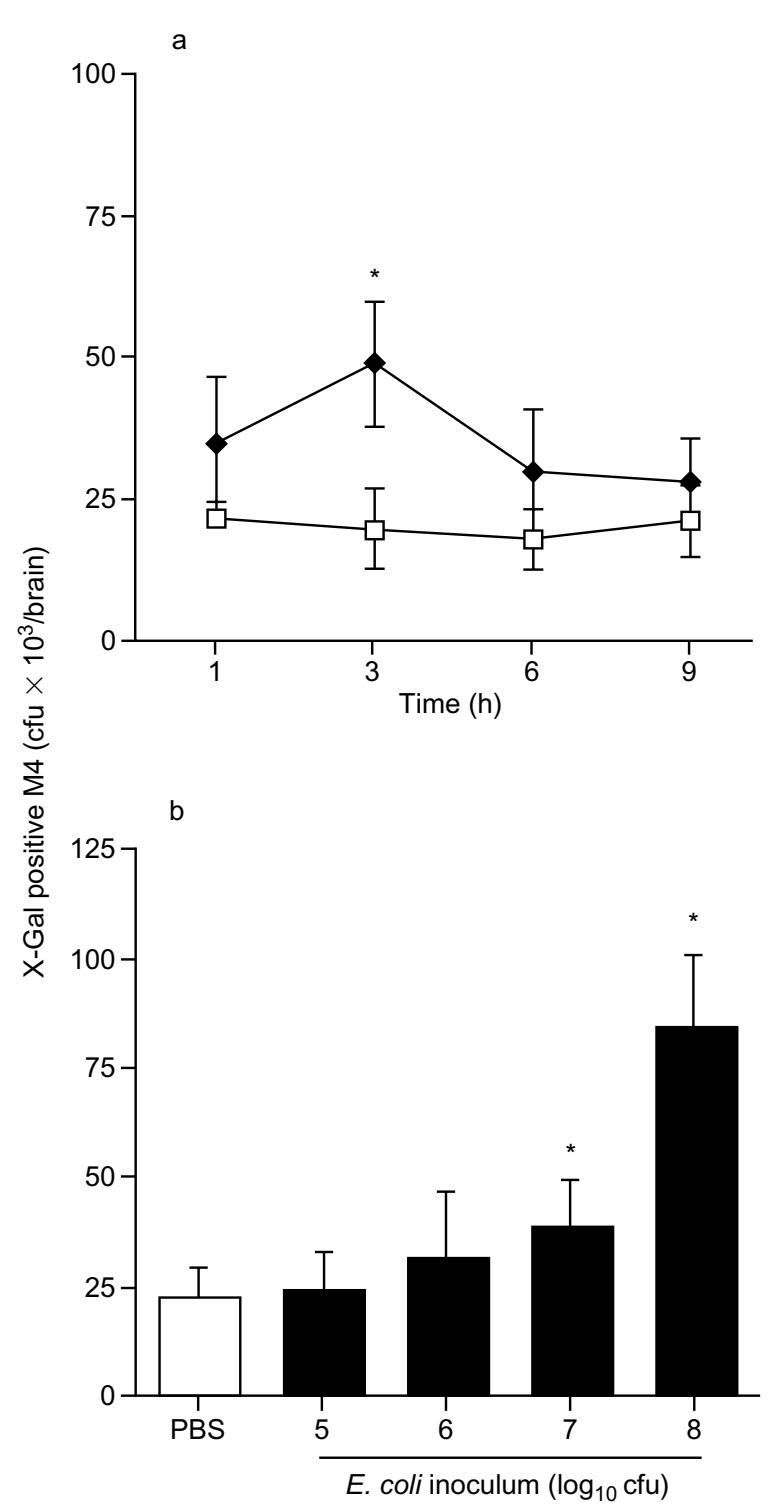

Fig. 2. Quantification of increased permeability of the $\mathrm{BBB}$ in E. coli-induced sepsis. (a) Kinetics of increased permeability of the BBB. Groups of four B6 mice were inoculated with $E$. coli $1 \times 10^{7}$ cells/mouse $(\bullet)$ or PBS ( $\square$ ) i.p. and killed at various time points after injection. (b) Dose-dependence of $E$. coli-induced increase of BBB permeability. Groups of four B6 mice were inoculated i.p. with various doses of $E$. coli and killed at $3 \mathrm{~h}$ after injection. The M4 tracers $\left(2 \times 10^{8}\right.$ cells $)$ were injected i.v. 2 min before each animal was killed. The cfus of XGal-positive M4 in brain homogenate were quantified. ${ }^{*} \mathrm{p}<0.05$ compared with the PBS-treated control mice. 


\section{Statistical analysis}

The significance of differences between treatment groups was determined by Student's $t$ test.

\section{Results}

Detection of increased $B B B$ permeability with the M4 tracer in E. coli- and S. pneumonia-induced sepsis

Intravenous injection of E. coli or $S$. pneumoniae induced sepsis and septic shock. An increase in BBB vasopermeability during the development of sepsis was detected with the M4 tracer that expressed $\beta$-galactosidase constitutively. The results showed that X-Galstained M4 cells were deposited in the parenchyma, beside the brain venules, as early as $1 \mathrm{~h}$ (Fig. 1b), and more were found in the parenchyma and meninges at $3 \mathrm{~h}$ than at $1 \mathrm{~h}$ or $6 \mathrm{~h}$ after injection of E. coli (Fig. 1c, d). However, the BBB was impermeable to the tracer at $9 \mathrm{~h}$ after injection (data not shown). The presence of XGal-positive M4 in the parenchyma of the brain indicated that the vasopermeability of $\mathrm{BBB}$ was increased sufficiently to allow a macromolecule such as E. coli M4 to cross the BBB. Nevertheless, there was no cell infiltration in the brain. To quantify the increase of BBB permeability, the numbers of M4 cells deposited in the brain were counted. As shown in Fig. $2 \mathrm{a}$, the permeability of the BBB increased from $1 \mathrm{~h}$ to $3 \mathrm{~h}$, then decreased at $6 \mathrm{~h}$ to a level similar to that of the PBS control (Fig. 2a). The maximal opening of the $\mathrm{BBB}$ was found at $3 \mathrm{~h}$ after injection, and the degree of opening was dependent upon the injected dose of $E$. coli (Fig. 2b).

The effect of gram-positive bacterium-induced sepsis on BBB permeability was also examined. As shown in Fig. 3, the BBB permeability was also increased after injection of $S$. pneumoniae, but with different kinetics from that of E. coli. The M4 tracers were not detected until $9 \mathrm{~h}$ after $S$. pneumoniae injection, and maximal numbers of M4 cells were found at $12 \mathrm{~h}$ (Fig. 3). The quantification of increased BBB permeability in $S$. pneumoniae sepsis is shown in Fig. 4.

The increase of BBB permeability during E. coliinduced sepsis was validated by the horseradish
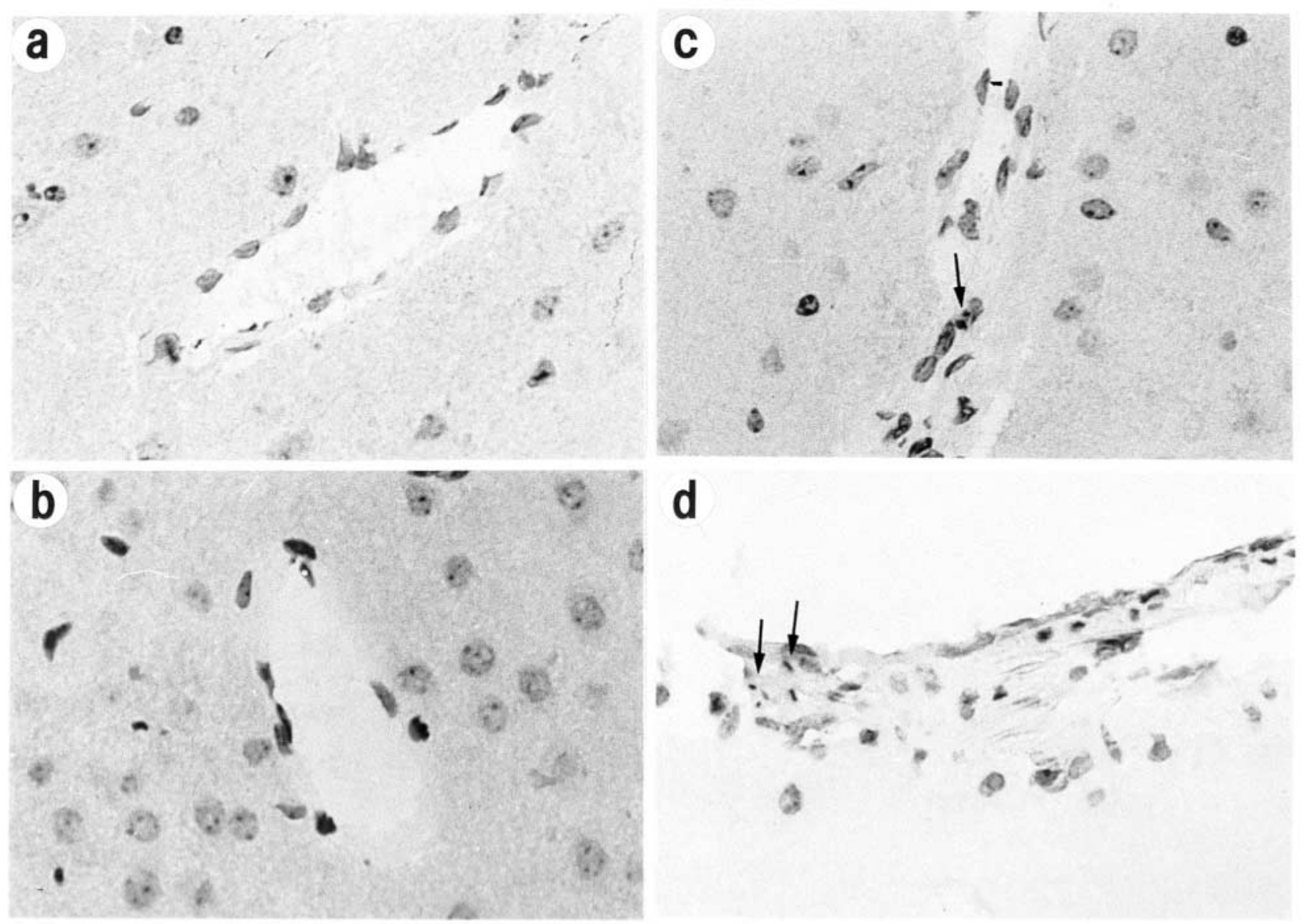

Fig. 3. Detection of the peripheral M4 tracer in brain by X-Gal staining in $S$. pneumoniae-induced sepsis. Groups of four B6 mice were inoculated i.p. with $S$. pneumoniae $1 \times 10^{7}$ cells/mouse and killed at various times after injection. PBS was used as a control. The M4 tracers $\left(2 \times 10^{8}\right.$ cells $)$ were injected i.v. 2 min before each animal was killed; $4-\mu \mathrm{m}$ sections of frozen brain tissues were stained with X-Gal as described in Materials and methods. (a) PBS, $12 \mathrm{~h}$; (b) $6 \mathrm{~h}$; (c) $9 \mathrm{~h}$; (d) $12 \mathrm{~h}(\times 350)$. Arrow indicates the X-Gal-positive M4. 


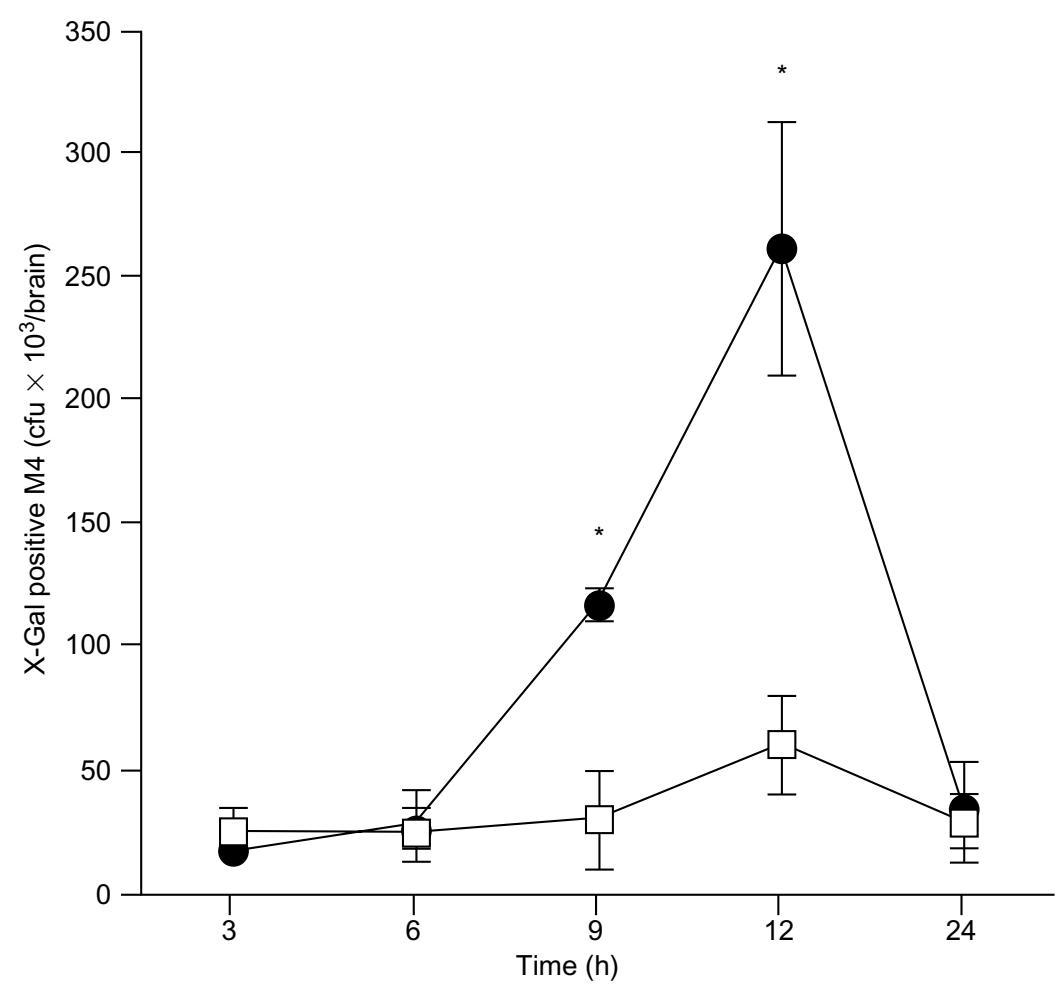

Fig. 4. Kinetics of increased permeability of the BBB in S. pneumoniae-induced sepsis. Groups of four B6 mice were inoculated i.p. with $1 \times 10^{7} \mathrm{~S}$. pneumoniae per mouse $(\bullet)$ or PBS $(\square)$ and killed at various time points after injection. The M4 tracers $\left(2 \times 10^{8}\right.$ cells) were injected i.v. 2 min before each animal was killed. The cfus of X-Gal-positive M4 in brain homogenate were quantified. ${ }^{*} \mathrm{p}<0.05$ compared with the PBS-treated control mice.

peroxidase leakage assay. Transmission electron microscopic examination of brain tissues revealed no change in tight junctions at $1 \mathrm{~h}$ after E. coli injection (Fig. 5b). However, exogenous horseradish peroxidase was found deposited along blood vessels at $3 \mathrm{~h}$ after injection, indicating that the microvascular vessels were leaky, and the astrocytes also showed a sign of slight activation as vacuoles in the cytoplasm (Fig. 5c). Thus, it was concluded that the BBB permeability could be increased transiently during sepsis.

\section{$T N F-\alpha$-induced alteration of $B B B$ permeability}

The factors involved in the increase of BBB permeability during E. coli- or S. pneumoniae-induced sepsis were examined. The distribution of TNF- $\alpha$ in brain was determined by immunohistochemical staining. TNF- $\alpha$ was stained on the meninges and venules from $1 \mathrm{~h}$ to $3 \mathrm{~h}$ after E. coli stimulation (Fig. $6 \mathrm{~b}$ and f), and had decreased by $6 \mathrm{~h}$ (data not shown). TNF- $\alpha$ was also detected on the meninges and venules of mice inoculated with $S$. pneumoniae, but at a later stage (6$12 \mathrm{~h}$ after injection) (Fig. 6c and g). Moreover, the brain venules in the parenchyma of mice treated with recombinant TNF- $\alpha$ also showed TNF- $\alpha$ staining (Fig. $6 \mathrm{~d}$ and $\mathrm{h}$ ). Furthermore, the increase of BBB permeability in either E. coli- or S. pneumoniae-induced sepsis could be inhibited by administration of antiTNF- $\alpha$ antibody (Fig. 7). The direct i.v. injection of recombinant TNF- $\alpha$, but not IL- $1 \beta$, induced the BBB opening at $3 \mathrm{~h}$ after injection in a dose-dependent manner (Fig. 8). These findings suggested that TNF- $\alpha$ was responsible for the alteration of $\mathrm{BBB}$ permeability.

\section{Rapid clearance of bacteria from blood in E. coli- and S. pneumoniae-induced sepsis}

Peritoneally administered $E$. coli or $S$. pneumoniae induced transient $\mathrm{BBB}$ opening. The number of $E$. coli or $S$. pneumoniae in blood after injection was determined. The results showed that no viable cells were detected $6 \mathrm{~h}$ after i.p. injection of $1 \times 10^{7} \mathrm{E}$. coli cells. The clearance rate of $S$. pneumoniae in blood was slower than that for E. coli, and all cells were removed within $12 \mathrm{~h}$ (Table 1 ).

\section{Discussion}

The blood-brain barrier, by virtue of its selective permeability, plays an important role in the migration of inflammatory cells into the brain micro-environment. The brain microvascular endothelial cells display several unique features such as the presence of tight junctions, no formation of pinocytotic vesicles, and wrapping by astrocytes that constitute part of the $\mathrm{BBB}$ [11-13]. The M4 tracer permitted not only detection of entry to the brain, but also quantification of the degree of increase in $\mathrm{BBB}$ permeability $[17,18]$. PBS treatment alone had no effect on $\mathrm{BBB}$ opening, but 


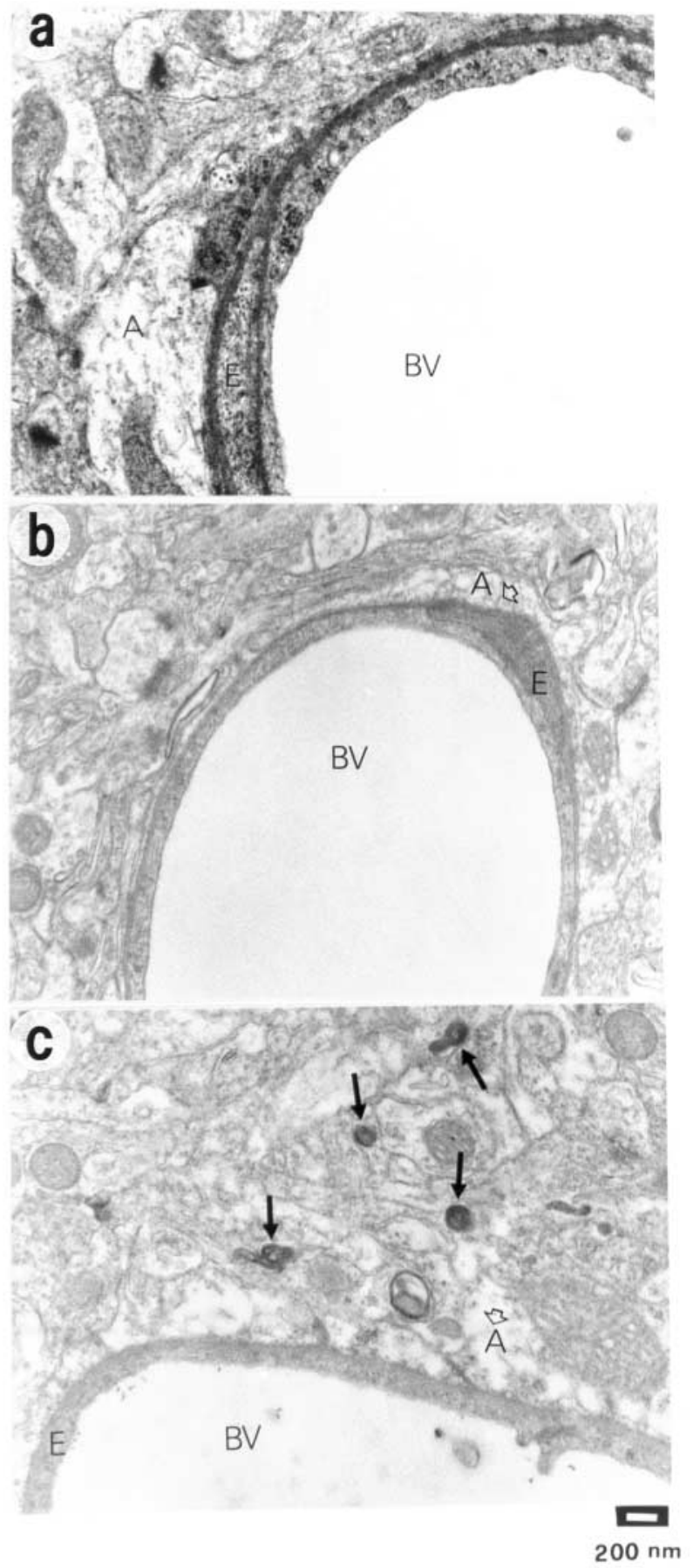

Fig. 5. The ultrastructural alteration of the BBB in $E$. coli-induced sepsis by transmission electron microscopy. Groups of three B6 mice were inoculated i.p. with $E$. coli $1 \times 10^{7}$ cells/mouse and killed at $1 \mathrm{~h}$ or $3 \mathrm{~h}$ after injection. PBS was used as a control. In (c), $5 \mathrm{mg}$ of horseradish peroxidase (as a tracer) was injected i.v. $10 \mathrm{~min}$ before the animal was killed. Brain tissues were prepared for electron microscopic examination as described in Materials and methods. (a) PBS, $3 \mathrm{~h}$; (b) $1 \mathrm{~h}$; (c) $3 \mathrm{~h}(\times 19000) . \rightarrow$, HRP; $\rightarrow \mathrm{A}$, impaired astrocyte; A, astrocyte; BV, blood vessel; E, endothelial cell.

both gram-negative and gram-positive bacterial sepsis induced an increase in BBB permeability. The reason for the kinetics of $S$. pneumoniae-induced increased BBB permeability being $9 \mathrm{~h}$ later than that observed in
E. coli treatment is probably due to differences in the kinetics of serum TNF- $\alpha$ production stimulated by gram-positive and gram-negative bacteria. In B6 mice, $E$. coli-induced serum TNF- $\alpha$ reached a peak at $1 \mathrm{~h}$, whereas with $S$. pneumoniae the peak was reached at $9 \mathrm{~h}$ [9]. The peptidoglycan and teichoic acid components of gram-positive bacteria are poorer TNF- $\alpha$ stimulators than the lipopolysaccharide (LPS) of gramnegative bacteria [22].

The increase in BBB permeability depended primarily on the action of TNF- $\alpha$ on microvascular vessels. The transmission electron microscopic examination of brain tissues stained with horseradish peroxidase also indicated leakage of microvascular vessels during sepsis. Endothelial cells respond to stimuli with acute alterations in mediator generation and surface expression. Vascular cells are both targets and sources of cytokines. These soluble mediators serve to communicate with leucocytes as well as other tissues and organs. Principal mediators in the pathology of sepsis are TNF- $\alpha$ and IL1 , which are released in large amounts by monocytes, macrophages and other leucocytes in response to bacterial toxins $[2,4,5,7]$. IL-1 and TNF- $\alpha$ induce production of several cytokines in endothelial cells, including various chemokines, colony-stimulating factor, IL-6, and IL-1 itself [23-25]. Endothelial cells respond to the cell wall of $S$. pneumoniae by TNF- $\alpha$ production [26], and TNF- $\alpha$ release by blood-derived infiltrating cells, but not endothelial cells, has also been reported in experimental pneumococcal meningitis [27]. An earlier study reported maximal production of serum TNF- $\alpha(7 \mathrm{ng} / \mathrm{ml})$ in B6 mice at $1 \mathrm{~h}$ and $9 \mathrm{~h}$ after $E$. coli and $S$. pneumoniae injection, respectively [9]. Direct i.v. injection of recombinant TNF- $\alpha$ not only induced BBB opening, but the venules in brain could also be stained with anti-TNF antibody. Endothelial cells are reported to express type I and type II TNF receptors, and the signal is mediated predominantly through the type I receptor [28-30]. In the present study, either TNF type I or type II receptors were manifested on brain venules in $E$. coli-induced sepsis (unpublished observations). The staining of TNF- $\alpha$ on endothelial cells in sepsis was probably due to the binding of circulatory TNF- $\alpha$ via a TNF receptor, but TNF- $\alpha$ produced by the endothelial cell response to stimuli was not excluded. There are discordant reports on whether direct injection of recombinant IL-1 into brain can induce CSF leucocytosis [31-33]. Intracerebral injection of $E$. coli induced the expression of IL$1 \beta$ in brain arteriole in an experimental meningitis mouse model [18], but IL- $1 \beta$ could not be detected after i.v. injection of $E$. coli (unpublished observations) nor did i.v. injection of recombinant IL- $1 \beta$ induce BBB breakdown. Although IL- $1 \beta$ will cause meningeal inflammation in synergy with TNF- $\alpha$, we believe that TNF- $\alpha$ is the major cytokine that induces the breakdown of BBB in sepsis.

The pathophysiology of bacterial meningitis involves 

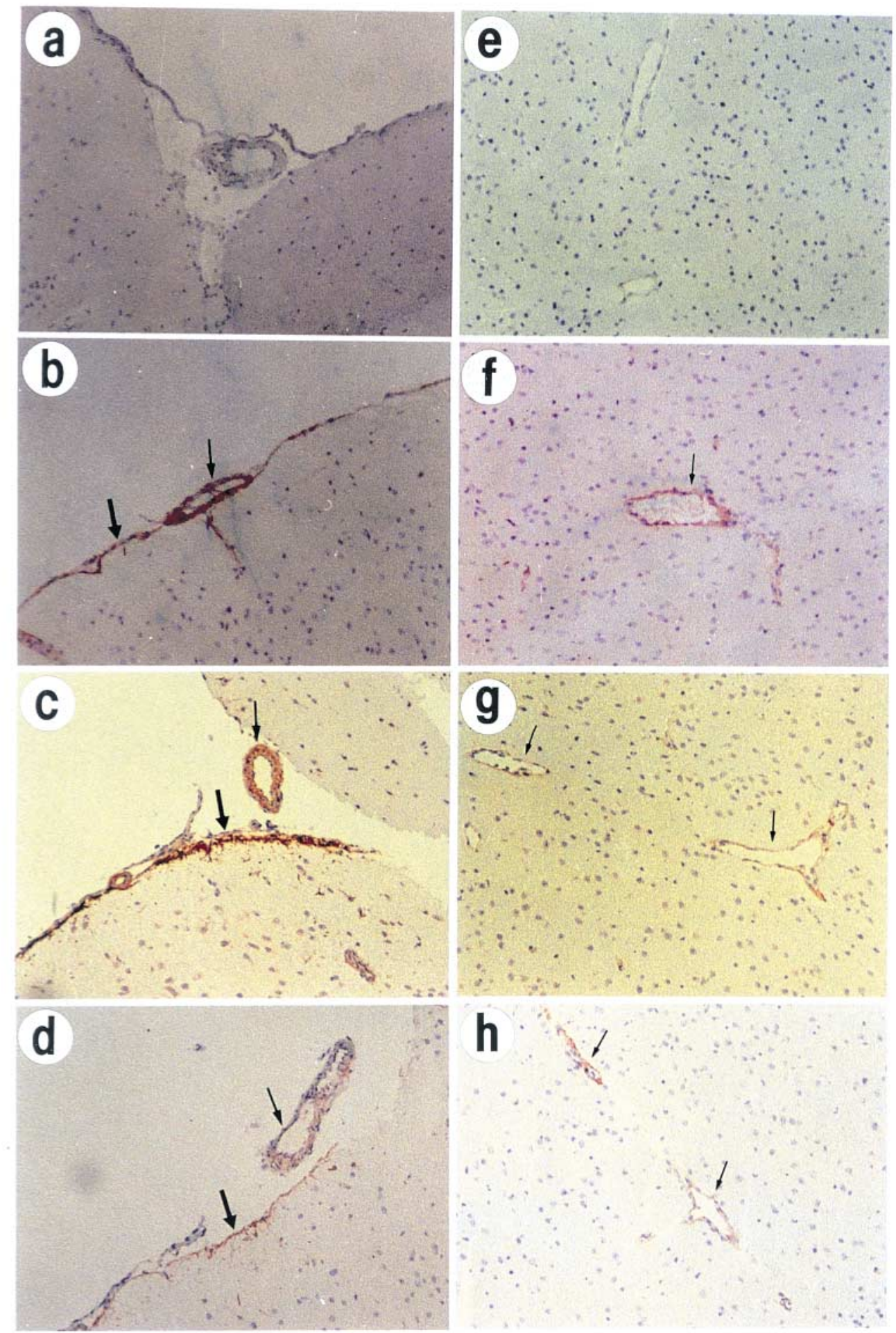

Fig. 6. TNF- $\alpha$ staining in brain after E. coli, $S$. pneumoniae or TNF- $\alpha$ stimulation. Groups of four B6 mice were inoculated i.p. with $E$. coli or $S$. pneumoniae $1 \times 10^{7}$ cells/mouse, or i.v. with TNF- $\alpha 120 \mathrm{ng} / \mathrm{mouse}$ and killed at $3 \mathrm{~h}$ (E. coli, TNF- $\alpha)$ or $12 \mathrm{~h}$ (S. pneumoniae) after injection. PBS was used as a control (a). Sections of frozen brain tissues $(4-\mu \mathrm{m})$ were stained with rat anti-TNF- $\alpha$ antibody as described in Materials and methods. (a) and (e) PBS; (b) and (f) E. coli; (c) and (g) S. pneumoniae; (d) and (h) TNF- $\alpha(\times 100)$. $\rightarrow$, venule; $\rightarrow$, arteriole; $\rightarrow$, meninges. Arrow indicates positive staining.

the invasion and multiplication of bacteria in the subarachnoidal space of the CNS. The bacterium itself, or its degraded products, stimulates the production and release of pro-inflammatory mediators such as cyto- kines and prostaglandins by leucocytes, endothelial cells, astrocytes, microglial cells and other cells in the $\mathrm{CNS}$, which subsequently lead to an increase in the permeability of the BBB. This would trigger transen- 


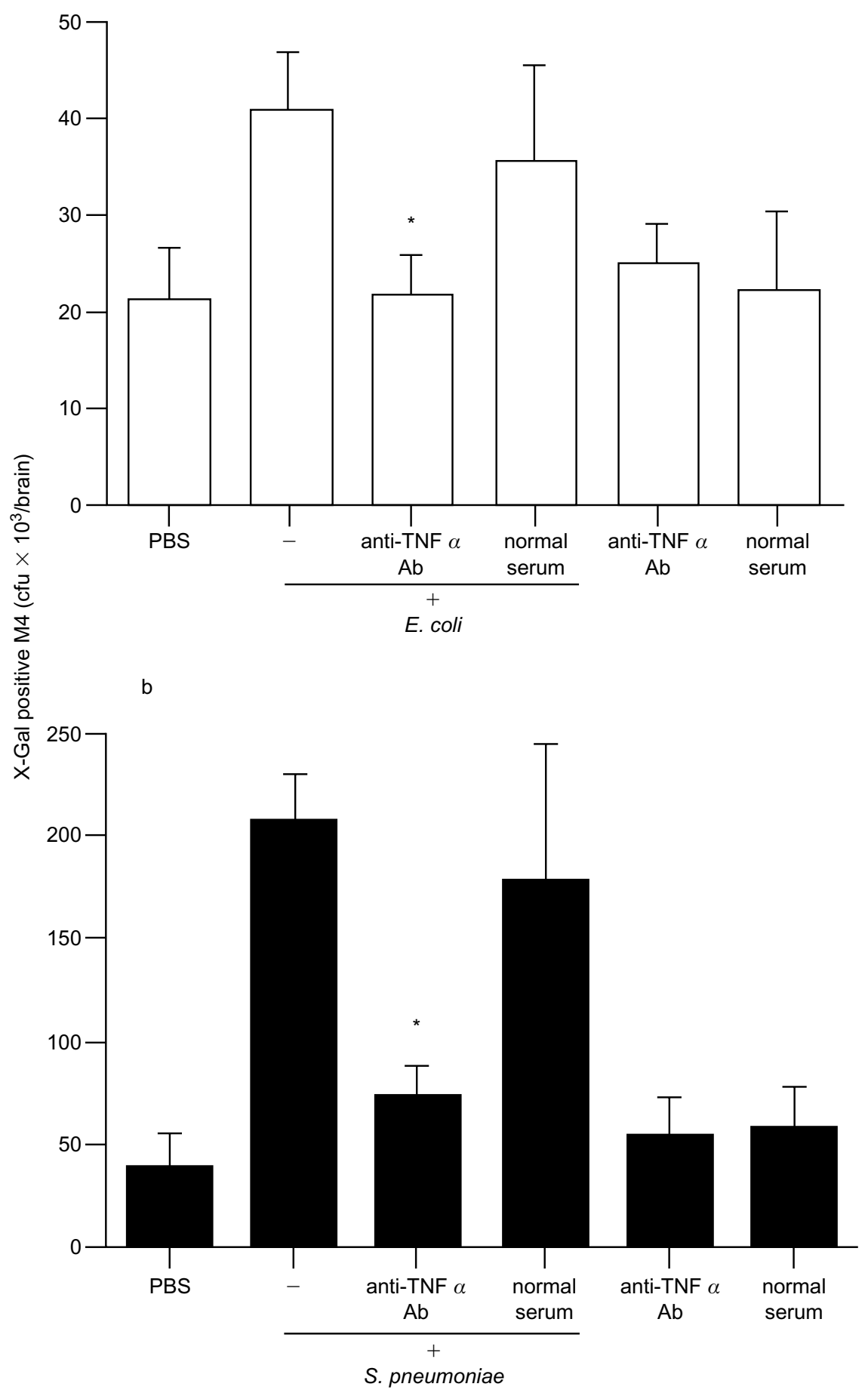

Fig. 7. Inhibition of increased permeability of the BBB in E. coli- or $S$. pneumoniae-induced sepsis by anti-TNF- $\alpha$ antibody. Groups of four B6 mice were inoculated i.p. with E. coli or $S$. pneumoniae $1 \times 10^{7}$ cells $/$ mouse and killed at $3 \mathrm{~h}$ (a) or $12 \mathrm{~h}$ (b), respectively, after injection. Rabbit anti-TNF- $\alpha$ antiserum (a, $40 \mu \mathrm{g} ; \mathrm{b}, 80 \mu \mathrm{g})$ was infected i.v. simultaneously. Normal rabbit serum was used a control. The M4 tracers $\left(2 \times 10^{8}\right.$ cells $)$ were administered i.v. 2 min before the animal was killed. The cfus of X-Gal-positive M4 in brain homogenate were quantified as described in Materials and methods. ${ }^{*} \mathrm{p}<0.05$ compared with the E. coli or $S$. pneumoniae-treated mice.

dothelial migration of neutrophils and leakage of plasma proteins that could further damage the brain $[14,34]$. However, it is not clear how the bacteria first enter the brain from a peripheral site. The observation in the present study that the TNF- $\alpha$ produced in the bloodstream by leucocytes during sepsis induced the increase in BBB permeability suggests the possibility that the peripheral bacteria may gain an entry to invade the brain through the BBB opening induced by TNF- $\alpha$. Because the bacteria did not replicate continuously in the blood, the BBB opening was transient. When more bacteria $\left(1 \times 10^{8}\right.$ cells $)$ were given, serum TNF- $\alpha$ was 


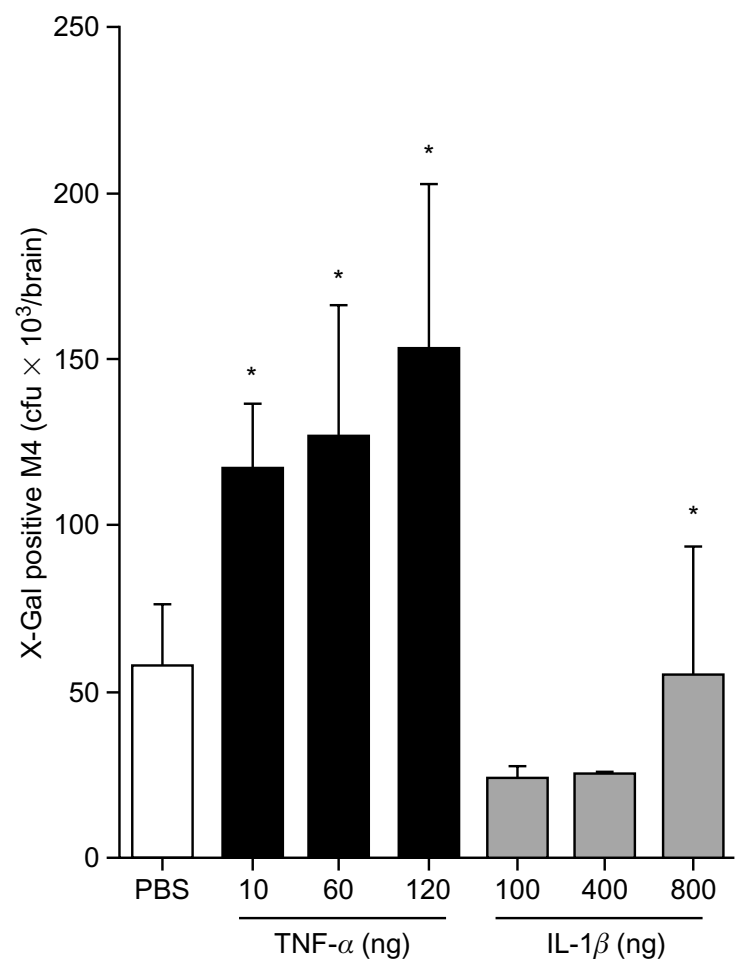

Fig. 8. Induction of the $\mathrm{BBB}$ opening by peripheral injection of TNF- $\alpha$, but not IL- $1 \beta$. Groups of four B6 mice were inoculated i.v. with mouse recombinant TNF- $\alpha$ $(10,60,120 \mathrm{ng} / \mathrm{mouse})$ or $\mathrm{IL}-1 \beta \quad(100,400$, $800 \mathrm{ng} / \mathrm{mouse})$. The mice were killed at $3 \mathrm{~h}$ after injection. The M4 tracers $\left(2 \times 10^{8}\right.$ cells $)$ were injected i.v. 2 min before the animal was killed. The cfus of $\mathrm{X}$ Gal-positive M4 in brain homogenate were quantified. ${ }^{*} \mathrm{p}<0.05$ compared with the PBS-treated control mice.

Table 1. Detection of viable bacteria in blood after intraperitoneal injection of E. coli or S. pneumoniae

\begin{tabular}{lcc}
\hline & \multicolumn{2}{c}{ Mean $(\mathrm{SD}) \mathrm{cfu} / \mathrm{ml}$} \\
\cline { 2 - 3 } Time $(\mathrm{h})$ & E. coli & S. pneumoniae \\
\hline 1 & $2.8(1.5) \times 10^{6}$ & $5.7(2.1) \times 10^{6}$ \\
3 & $4.2(1.1) \times 10^{2}$ & $2.1(1.0) \times 10^{6}$ \\
6 & $\mathrm{ND}$ & $8.7(2.1) \times 10^{4}$ \\
9 & $\mathrm{ND}$ & $4.1(1.8) \times 10^{1}$ \\
12 & $\mathrm{ND}$ & $\mathrm{ND}$ \\
\hline
\end{tabular}

Groups of four mice were inoculated intraperitoneally with $1 \times 10^{7}$ E. coli or S. pneumoniae. Blood was collected at various time points after treatment. The remnant bacteria in blood were quantified as described in Materials and methods. ND, not detectable.

maintained at a high level and the BBB opening was sustained continuously (unpublished observations). Once foreign bacteria replicate effectively in the blood, they may gain a niche in the subarachnoidal space by TNF- $\alpha$-induced BBB opening. They can then replicate and stimulate more cytokine production, further increase the permeability of $\mathrm{BBB}$, and induce the infiltration of neutrophils that constitutes the vicious cycle of bacterial meningitis.

This work was supported by grant NHRI-GT-EX89B717L from the National Health Research Institute of the Department of Health of the Republic of China.

\section{References}

1. Glauser MP, Zanetti G, Baumgartner J-D, Cohen J. Septic shock: pathogenesis. Lancet 1991; 338: 732-736.

2. Cohen J, Glauser MP. Septic shock: treatment. Lancet 1991; 338: 736-739.

3. Morrison DC, Ryan JL. Endotoxins and disease mechanisms. Annu Rev Med 1987; 38: 417-432.

4. Billiau A, Vandekerckhove F. Cytokines and their interactions with other inflammatory mediators in the pathogenesis of sepsis and septic shock. Eur J Clin Invest 1991; 21: 559-573.

5. Calandra T, Baumgartner J-D, Grau GE et al. Prognosis values of tumor necrosis/cachectin, interleukin-1, alpha-interferon and gamma-interferon in the serum of patients with septic shock. $J$ Infect Dis 1990; 161: 982-987.

6. Girardin E, Grau GE, Dayer J-M, Roux-Lombard P, the J-S Study Group, Lambert P-H. Tumor necrosis factor and interleukin-1 in the serum of children with severe infectious purpura. N Engl J Med 1988; 319: 397-400.

7. Gutierrez-Ramos JC, Bluethmann H. Molecules and mechanisms operating in septic shock: lessons from knockout mice. Immunol Today 1997; 18: 329-334.

8. Waage A, Halstensen A, Espevik T. Association between tumor necrosis factor in serum and fatal outcome in patients with meningococcal disease. Lancet 1987; 1: 355-357.

9. Wang S-D, Huang K-J, Lin Y-S, Lei H-Y. Sepsis-induced apoptosis of the thymocytes in mice. J Immunol 1994; 152: 5014-5021.

10. Deng $X$, Wang $X$, Andersson R. Alterations in endothelial barrier permeability in multiple organs during overactivation of macrophages in rats. Shock 1996; 6: 126-133.

11. Abbott NJ, Romero IA. Transporting therapeutics across the blood-brain barrier. Mol Med Today 1996; 2: 106-113.

12. Perry VH, Anthony DC, Bolton SJ, Brown HC. The bloodbrain barrier and the inflammatory response. Mol Med Today 1997; 3: 335-341.

13. Janzer RC, Raff MC. Astrocytes induce blood-brain barrier properties in endothelial cells. Nature 1987; 325: 253-257.

14. Van Furth AM, Roord JJ, van Furth R. Roles of proinflammatory and anti-inflammatory cytokines in pathophysiology of bacterial meningitis and effect of adjunctive therapy. Infect Immun 1996; 64: 4883-4890.

15. Chang YC, Huang CC, Wang ST, Liu CC, Tsai JJ. Risk factors analysis for early fatality in children with acute bacterial meningitis. Pediatr Neurol 1998; 18: 213-217.

16. Liu CC, Chen JS, Lin CH, Chen YJ, Huang CC. Bacterial meningitis in infants and children in southern Taiwan: emphasis on Haemophilus influenzae type B infection. J Formos Med Assoc 1993; 92: 884-888.

17. Tsao N, Hsu HP, Lei HY. TNF- $\alpha$-induced cyclooxygenase 2 not only increases the vasopermeability of blood-brain barrier but also enhances the neutrophil survival in Escherichia coliinduced brain inflammation. Prostaglandins Lipid Mediat 1999; 57: $371-382$.

18. Tsao N, Kanakamma PP, Luh T-Y, Chou C-K, Lei H-Y. The inhibition of Escherichia coli-induced meningitis by carboxyfullerence. Antimicrob Agents Chemother 1999; 43: 2273-2277.

19. Ho T-S, Tsai C-Y, Tsao N, Chow N-H, Lei H-Y. Infiltrated cells in experimental allergic encephalomyelitis by additional intracerebral injection in myelin-basic-protein-sensitized B6 mice. J Biomed Sci 1997; 4: 300-307.

20. Lossinsky AS, Vorbrodt AW, Wisniewski HM. Scanning and transmission electron microscopic studies of microvascular pathology in the osmotically impaired blood-brain barrier. $J$ Neurocytol 1995; 24: 795-806.

21. Reese TS, Karnovsky MJ. Fine structural localization of a blood-brain barrier to exogenous peroxidase. J Cell Biol 1967; 34: $207-217$.

22. Toumanen $\mathrm{E}$, Tomasz $\mathrm{A}$, Hengstler $\mathrm{B}, \mathrm{Zak} \mathrm{O}$. The relative role of bacterial cell wall and capsule in the induction of inflammation in pneumococcal meningitis. J Infect Dis 1985; 151: $535-540$

23. Mantovani A, Bussolino F, Introna M. Cytokine regulation of endothelial cell function: from molecular level to the bedside. Immunol Today 1997; 18: 231-240.

24. Mantovani A, Bussolino F, Dejana E. Cytokine regulation of endothelial cell function. FASEB $J$ 1992; 6: 2591-2599. 
25. Pober JS, Cotran RS. Cytokines and endothelial cell biology. Physiol Rev 1990; 70: 427-451.

26. Freyer D, Manz R, Ziegenhorn A et al. Cerebral endothelial cells release TNF- $\alpha$ after stimulation with cell walls of Streptococcus pneumoniae and regulate inducible nitric oxide synthase and ICAM-1 expression via autocrine loops. $J$ Immunol 1999; 163: 4308-4314.

27. Bitsch A, Trostdorf F, Brück W, Schmidt H, Fischer FR, Nau R. Central nervous system TNF $\alpha$-mRNA expression during rabbit experimental pneumococcal meningitis. Neurosci Lett 1997; 237: 105-108.

28. Bradley JR, Thiru S, Pober JS. Disparate localization of 55-kd and 75-kd tumor necrosis factor receptors in human endothelial cells. Am J Pathol 1995; 146: 27-32.

29. Mackay F, Loetscher H, Stueber D, Gehr G, Lesslauer W. Tumor necrosis factor alpha (TNF-alpha)-induced cell adhesion to human endothelial cells is under dominant control of one TNF receptor type, TNF-R55. J Exp Med 1993; 177: $1277-1286$.
30. Paleolog EM, Delasalle S-AJ, Buurman WA, Feldmann M Functional activities of receptor for tumor necrosis factor-alpha on human vascular endothelial cells. Blood 1994; 84: $2578-2590$.

31. Quagliarello VJ, Wispelwey B, Long WJ, Scheld WM Recombinant human interleukin-1 induces meningitis and blood-brain barrier injury in the rat. Characterization and comparison with tumor necrosis factor. J Clin Invest 1991; 87: $1360-1366$

32. Ramilo O, Sáez-Llorens X, Mertsola $\mathrm{J}$ et al. Tumor necrosis factor $\alpha /$ cachectin and interleukin $1 \beta$ initiate meningeal inflammation. $J$ Exp Med 1990; 172: 497-507.

33. Saukkonen K, Sande S, Cioffe C et al. The role of cytokines in the generation of inflammation and tissue damage in experimental gram-positive meningitis. J Exp Med 1990; 171: 439-448.

34. Quagliarello V, Scheld WM. Bacterial meningitis: pathogenesis, pathophysiology, and progress. $N$ Engl J Med 1992; 327: 864-872. 